\title{
Research on the Characteristics of Chongqing Elderly Care Enterprises Cluster
}

\author{
Hong Hui*, Lingyan Liao \\ School of Business Administration, Chongqing University of Technology, Chongqing, China \\ Email: ^hhzrj@cqut.edu.cn
}

How to cite this paper: Hui, H., \& Liao, L. Y. (2021). Research on the Characteristics of Chongqing Elderly Care Enterprises Cluster. American Journal of Industrial and Business Management, 11, 321-328. https://doi.org/10.4236/ajibm.2021.114020

Received: March 22, 2021

Accepted: April 11, 2021

Published: April 14, 2021

Copyright $\odot 2021$ by author(s) and Scientific Research Publishing Inc. This work is licensed under the Creative Commons Attribution International License (CC BY 4.0).

http://creativecommons.org/licenses/by/4.0/

\begin{abstract}
In recent years, the problem of aging is becoming more and more serious, which is the core problem of the whole society. Through the research of elderly care enterprises in Chongqing, we find that there are 17 regional elderly care enterprise clusters in Chongqing. Through the further analysis of the data within the cluster, it is found that the areas with high concentration of elderly care enterprises cluster are mainly reflected in the large number and large scale, but the industrial richness is not high; while the regions with higher industrial cluster richness belong to small-scale industrial clusters.
\end{abstract}

\section{Keywords}

Elderly Care Industry, Industrial Cluster, Richness Distribution

\section{Introduction}

In recent years, the issue of aging has become the focus of attention of the whole society. China's aging has a series of characteristics, such as rapid entry, large base, rapid growth (Yan, Huang, \& Zheng, 2021). By the end of 2019, there are 254 million elderly people over 60 years old in China, accounting for $18.1 \%$ of the total population; and there are 718.94 elderly people aged 60 and above in Chongqing, accounting for $21.12 \%$ of the total population (Chongqing Statistical Information Network, 2019). Therefore, the development of elderly care enterprises is a concern of the whole society (Mu, 2012; Song, Zhao, \& Wang, 2018). According to the general research, the elderly care enterprises cover a large number of fields, which integrates the production, operation and service of elderly care products, and spans the first, second, third and fourth (Information Industry) industries (Zhai, 2013). The elderly care enterprises cluster refers to a large number of enterprises with different scales and grades with division and cooperation relationship in a certain space area, and various institutions, organ- 
izations and other actors related to their development and they are closely linked together through crisscross network relations, representing a new elderly care between the market and the hierarchic Organizational form (Xu, 2013). There are also relevant studies on the elderly care enterprises cluster from the perspective of coordinated development of elderly care community, elderly care complex, elderly care enterprises and medical insurance industry (Yan, 2008), but on the whole, there is a lack of research on the industry cluster from the overall macro perspective. He \& Li (2020) studies the cluster of Chinese elderly care enterprises from the perspective of theoretical analysis, but lacks specific data.

This research uses the data provided by the "Enterprise Check" software to sort out the number, location, registered capital, and operating field information of Chongqing's elderly care enterprises, and then uses ArcGIS to analyze the spatial distribution of elderly care enterprises and perform related calculations. Get. Through the analysis of the spatial pattern and industry distribution of Chongqing's elderly care enterprises, further research is carried out on the richness, scale, advantageous industries, age and other characteristics of the elderly care industry clusters in order to discover the characteristics and deficiencies of the industrial clusters of Chongqing elderly care enterprises

\section{Spatial Pattern of Elderly Care Enterprises in Chongqing}

From the distribution of districts and counties, elderly care enterprises are mainly concentrated in the nine districts of the main city and Jiangjin district. The districts and counties with more than 300 enterprises are Yubei District, Jiulongpo District, Shapingba District, Jiangbei District, Yuzhong District, Nan'an District and Jiangjin district. By analyzing the spatial distribution of elderly care enterprises in Chongqing with ArcGIS (Figure 1), it found that the spatial pattern has the following characteristics: Generally speaking, it presents a distribution pattern of "weak in the East and strong in the west". The high-density gathering area mainly appears in the main urban area, and the more eastward the cluster area is, the weaker the aggregation is, which shows that the development level of the city largely determines the distribution of elderly care enterprises.

As shown in the the core density map of Chongqing elderly care enterprises (Figure 2), there are 17 main concentration areas, including Kaizhou, Wanzhou, Hechuan, Beibei, Yubei, Yongchuan, Jiulongpo, Dianjiang, Zhongxian, Fengdu, Fuling, Nanchuan, Qijiang and Yuzhong.

\section{Industry Distribution Pattern of Elderly Care Enterprises}

According to the current registered business scope, elderly care enterprises can be divided into 20 industries, including real estate industry, residential service industry, elderly care institutions, financial industry, transportation industry, catering and accommodation industry, wholesale and retail, health and social 


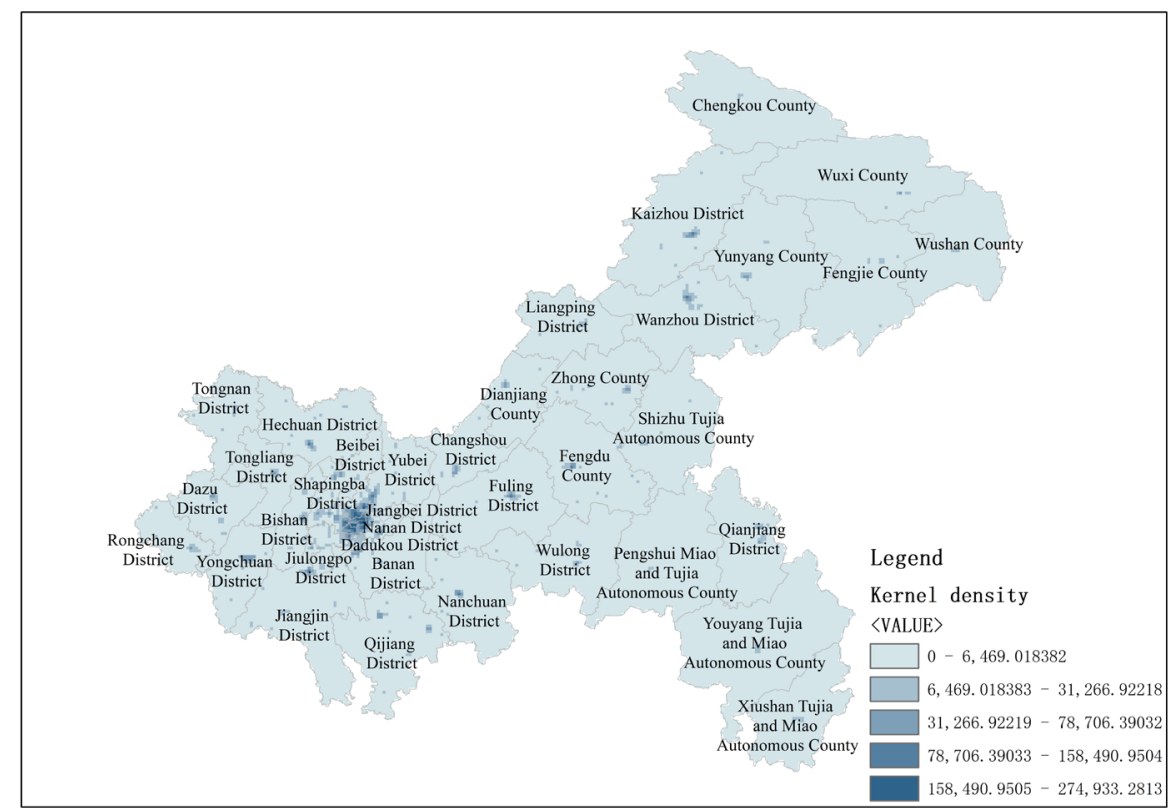

Figure 1. Core density of elderly care enterprises in Chongqing.

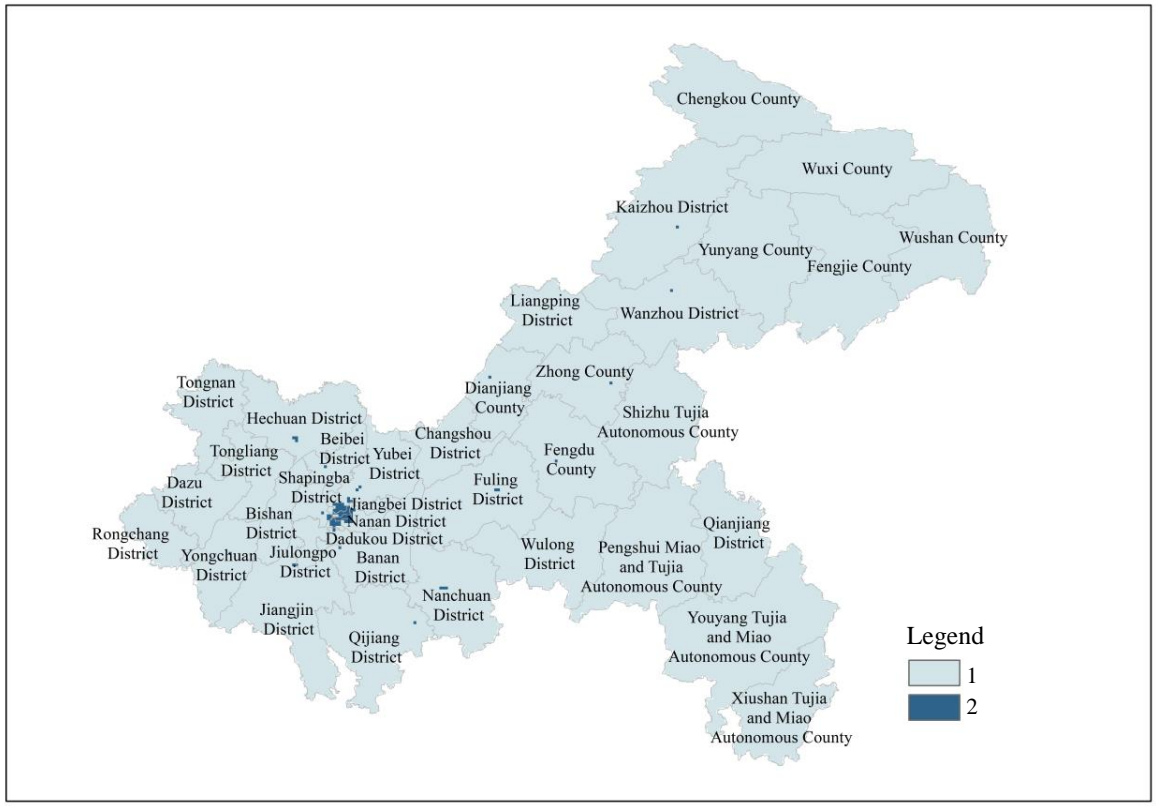

Figure 2. Core density binarization of elderly care enterprises in Chongqing.

work, leasing and business services. Among them, more than 1000 enterprises are engaged in leasing and business services, elderly care institutions, health and social work (Table 1 ).

\section{Evaluation and Analysis on the Industrial Cluster of Elderly Care Enterprises}

\subsection{Analysis of Industrial Cluster Richness}

In ecology, Simpson diversity index is usually used to describe the biodiversity of 
Table 1. Number of elderly care enterprises in Chongqing (Source: Enterprise Check Software).

\begin{tabular}{|c|c|c|c|}
\hline category & number & category & number \\
\hline Mining industry & 4 & $\begin{array}{l}\text { Agriculture, forestry, animal } \\
\text { husbandry and fishery }\end{array}$ & 462 \\
\hline $\begin{array}{l}\text { Electricity, heat, gas and water } \\
\text { production and supply industry }\end{array}$ & 6 & Wholesale and retail & 980 \\
\hline estate & 312 & $\begin{array}{l}\text { Water conservancy, environment } \\
\text { and public facilities management }\end{array}$ & 82 \\
\hline $\begin{array}{c}\text { Public administration, social } \\
\text { security and social organization }\end{array}$ & 4 & Health and social work & 1712 \\
\hline construction business & 108 & Culture, sports and entertainment & 115 \\
\hline $\begin{array}{l}\text { Transportation, warehousing and } \\
\text { postal services }\end{array}$ & 14 & $\begin{array}{l}\text { Information transmission, software } \\
\text { and information technology services }\end{array}$ & 209 \\
\hline education & 29 & Nursing homes and services & 1106 \\
\hline finance & 39 & manufacturing industry & 80 \\
\hline $\begin{array}{l}\text { Residential services, } \\
\text { repair and other services }\end{array}$ & 822 & Accommodation and catering & 140 \\
\hline $\begin{array}{l}\text { Scientific research } \\
\text { and technical services }\end{array}$ & 216 & Leasing and business services & 1166 \\
\hline total & 7606 & & \\
\hline
\end{tabular}

a region. According to the calculation formula of Simpson diversity index, the formula for evaluating the industrial richness of a region is derived as follows,

$$
D=\frac{\sum_{i=1}^{k} n_{i}\left(n_{i}-1\right)}{N(N-1)},
$$

where, $D$ is the richness index, $K$ is the number of enterprise categories, $I$ is the type $I$ enterprises, $n_{i}$ is the number of type $I$ enterprises in the region, and $N$ is the total number of enterprises in the region. The higher the value of $D$, the lower the regional industrial cluster richness; conversely, the higher the regional industrial cluster richness.

The results are shown in Table 2.

According to the comparison of the number and richness index of enterprises in different regions, it can be seen that the industrial cluster richness of Kaizhou cluster, Zhongxian cluster, Yongchuan and Shapingba cluster is low, while that of Qijiang cluster, Dianjiang, Banan, Fuling, Yubei, Yubei-Jiangbei and Yuzhong cluster is reallyhigh.

\subsection{Analysis of Industrial Cluster Scale}

The total amount of registered capital of elderly care enterprises in each cluster area is obtained by summation calculation, as shown in Table 3. It is found that the industrial cluster scale of Yuzhong cluster is the largest, followed by Yubei Jiangbei cluster and Nanchuan cluster, while Banan cluster is the smallest. 
Table 2. Richness index of each aggregation area.

\begin{tabular}{|c|c|c|c|c|c|c|}
\hline & $\begin{array}{c}\text { Kaizhou } \\
\text { gathering area }\end{array}$ & $\begin{array}{c}\text { Wanzhou } \\
\text { gathering area }\end{array}$ & $\begin{array}{c}\text { Hechuan } \\
\text { gathering area }\end{array}$ & $\begin{array}{c}\text { Beibei } \\
\text { gathering area }\end{array}$ & $\begin{array}{c}\text { Yubei } \\
\text { gathering area }\end{array}$ & $\begin{array}{l}\text { Yubei Jiangbei } \\
\text { gathering area }\end{array}$ \\
\hline \multirow[t]{2}{*}{ Richness index } & 0.2159 & 0.1899 & 0.1474 & 0.1471 & 0.1311 & 0.1298 \\
\hline & $\begin{array}{l}\text { Shapingba } \\
\text { gathering area }\end{array}$ & $\begin{array}{c}\text { Banan } \\
\text { gathering area }\end{array}$ & $\begin{array}{l}\text { Yongchuan } \\
\text { gathering area }\end{array}$ & $\begin{array}{l}\text { Jiulongpo Jiangjin } \\
\text { gathering area }\end{array}$ & $\begin{array}{c}\text { Dianjiang } \\
\text { gathering area }\end{array}$ & $\begin{array}{c}\text { Zhongxian } \\
\text { gathering area }\end{array}$ \\
\hline \multirow[t]{2}{*}{ Richness index } & 0.1852 & 0.1311 & 0.1818 & 0.1422 & 0.1262 & 0.2651 \\
\hline & $\begin{array}{c}\text { Fengdu } \\
\text { gathering area }\end{array}$ & $\begin{array}{c}\text { Fuling } \\
\text { gathering area }\end{array}$ & $\begin{array}{c}\text { Nanchuan } \\
\text { gathering area }\end{array}$ & $\begin{array}{l}\text { Qijiang } \\
\text { gathering area }\end{array}$ & $\begin{array}{c}\text { Yuzhong } \\
\text { gathering area }\end{array}$ & \\
\hline Richness index & 0.1778 & 0.1331 & 0.1444 & 0.1111 & 0.1341 & \\
\hline
\end{tabular}

Table 3. Number and registered capital of elderly care enterprises in each cluster area.

\begin{tabular}{|c|c|c|c|c|c|c|}
\hline & $\begin{array}{c}\text { Kaizhou } \\
\text { gathering area }\end{array}$ & $\begin{array}{c}\text { Wanzhou } \\
\text { gathering area }\end{array}$ & $\begin{array}{c}\text { Hechuan } \\
\text { gathering area }\end{array}$ & $\begin{array}{c}\text { Beibei } \\
\text { gathering area }\end{array}$ & $\begin{array}{c}\text { Yubei } \\
\text { gathering area }\end{array}$ & $\begin{array}{l}\text { Yubei Jiangbe } \\
\text { gathering area }\end{array}$ \\
\hline number & 43 & 45 & 75 & 30 & 61 & 115 \\
\hline \multirow[t]{2}{*}{$\begin{array}{l}\text { Registered capital } \\
\quad(\text { RMB 10,000) }\end{array}$} & $51,221.0$ & $314,464.3$ & $257,769.1$ & $23,041.5$ & $217,717.0$ & $491,569.5$ \\
\hline & $\begin{array}{l}\text { Shapingba } \\
\text { gathering area }\end{array}$ & $\begin{array}{c}\text { Banan } \\
\text { gathering area }\end{array}$ & $\begin{array}{l}\text { Yongchuan } \\
\text { gathering area }\end{array}$ & $\begin{array}{l}\text { Jiulongpo Jiangjin } \\
\text { gathering area }\end{array}$ & $\begin{array}{c}\text { Dianjiang } \\
\text { gathering area }\end{array}$ & $\begin{array}{l}\text { Zhongxian } \\
\text { gathering area }\end{array}$ \\
\hline number & 28 & 35 & 34 & 78 & 26 & 36 \\
\hline \multirow[t]{2}{*}{$\begin{array}{l}\text { Registered capital } \\
\quad(\mathrm{RMB} 10,000)\end{array}$} & $17,199.0$ & 9047.0 & $18,733.0$ & $123,876.0$ & $54,818.1$ & $92,561.0$ \\
\hline & $\begin{array}{c}\text { Fengdu } \\
\text { gathering area }\end{array}$ & $\begin{array}{c}\text { Fuling } \\
\text { gathering area }\end{array}$ & $\begin{array}{c}\text { Nanchuan } \\
\text { gathering area }\end{array}$ & $\begin{array}{c}\text { Qijiang } \\
\text { gathering area }\end{array}$ & $\begin{array}{l}\text { Yuzhong } \\
\text { gathering area }\end{array}$ & \\
\hline number & 38 & 63 & 101 & 28 & 2094 & \\
\hline $\begin{array}{l}\text { Registered capital } \\
(\mathrm{RMB} 10,000)\end{array}$ & $51,353.0$ & $39,520.7$ & $640,597.0$ & $274,145.2$ & $5,480,068.7$ & \\
\hline
\end{tabular}

\subsection{Age Analysis of Industrial Clusters}

According to the establishment date of elderly care enterprises in each cluster area, the operation duration of elderly care enterprises is calculated, and the average operation time of elderly care enterprises in each cluster area is calculated to obtain the average age of elderly care enterprises in each cluster area, as shown in Table 4. In general, the age of industrial clusters in the main urban agglomeration areas is relatively small, while the age of industrial clusters in Fuling, Qijiang and Wanzhou is relatively older.

\subsection{Analysis of Advantageous Enterprises in Industrial Cluster}

According to the number of various elderly care enterprises and the total number of enterprises in each cluster area, the percentage of various elderly care enterprises in each cluster area is obtained, and the advantage enterprises in each cluster area are compared, as shown in Table 5. On the whole, the dominant enterprises are mainly health and social work enterprises, residents' service, 
Table 4. Average age of elderly care enterprises in each cluster area.

\begin{tabular}{|c|c|c|c|c|c|c|}
\hline & $\begin{array}{c}\text { Kaizhou } \\
\text { gathering area }\end{array}$ & $\begin{array}{c}\text { Wanzhou } \\
\text { gathering area }\end{array}$ & $\begin{array}{c}\text { Hechuan } \\
\text { gathering area }\end{array}$ & $\begin{array}{c}\text { Beibei } \\
\text { gathering area }\end{array}$ & $\begin{array}{c}\text { Yubei } \\
\text { gathering area }\end{array}$ & $\begin{array}{l}\text { Yubei Jiangbei } \\
\text { gathering area }\end{array}$ \\
\hline \multirow[t]{2}{*}{ Average age of enterprise } & 3.1 & 5.8 & 4 & 3.8 & 3.5 & 3.7 \\
\hline & $\begin{array}{l}\text { Shapingba } \\
\text { gathering area }\end{array}$ & $\begin{array}{c}\text { Banan } \\
\text { gathering area }\end{array}$ & $\begin{array}{l}\text { Yongchuan } \\
\text { gathering area }\end{array}$ & $\begin{array}{l}\text { Jiulongpo Jiangjin } \\
\text { gathering area }\end{array}$ & $\begin{array}{l}\text { Dianjiang } \\
\text { gathering area }\end{array}$ & $\begin{array}{l}\text { Zhongxian } \\
\text { gathering area }\end{array}$ \\
\hline \multirow[t]{2}{*}{ Average age of enterprise } & 4.7 & 3.5 & 4.3 & 3.6 & 3.1 & 4.2 \\
\hline & $\begin{array}{l}\text { Fengdu } \\
\text { gathering area }\end{array}$ & $\begin{array}{c}\text { Fuling } \\
\text { gathering area }\end{array}$ & $\begin{array}{c}\text { Nanchuan } \\
\text { gathering area }\end{array}$ & $\begin{array}{l}\text { Qijiang } \\
\text { gathering area }\end{array}$ & $\begin{array}{l}\text { Yuzhong } \\
\text { gathering area }\end{array}$ & \\
\hline Average age of enterprise & 3.3 & 6.1 & 4.2 & 5.9 & 3.8 & \\
\hline
\end{tabular}

Table 5. Advantageous enterprises in each cluster area.

\begin{tabular}{|c|c|c|c|c|c|c|}
\hline & $\begin{array}{c}\text { Kaizhou } \\
\text { gathering area }\end{array}$ & $\begin{array}{c}\text { Wanzhou } \\
\text { gathering area }\end{array}$ & $\begin{array}{c}\text { Hechuan } \\
\text { gathering area }\end{array}$ & Beibei gathering area & $\begin{array}{c}\text { Yubei } \\
\text { gathering area }\end{array}$ & $\begin{array}{l}\text { Yubei Jiangbei } \\
\text { gathering area }\end{array}$ \\
\hline $\begin{array}{c}\text { Advantageous } \\
\text { enterprises }\end{array}$ & $\begin{array}{l}\text { 1) Health and social } \\
\text { work }\end{array}$ & $\begin{array}{l}\text { 1) Residential services, } \\
\text { repair and other } \\
\text { services } \\
\text { 2) Health and social } \\
\text { work }\end{array}$ & $\begin{array}{l}\text { 1) Health and social } \\
\text { work } \\
\text { 2) Residential } \\
\text { services, repair and } \\
\text { other services }\end{array}$ & $\begin{array}{l}\text { 1) Health and social } \\
\text { work } \\
\text { 2) Nursing homes } \\
\text { and services }\end{array}$ & $\begin{array}{l}\text { 1) Health and } \\
\text { social work }\end{array}$ & $\begin{array}{l}\text { 1) Leasing and } \\
\text { business services }\end{array}$ \\
\hline \multirow{3}{*}{$\begin{array}{l}\text { Advantageous } \\
\text { enterprises }\end{array}$} & $\begin{array}{l}\text { Shapingba } \\
\text { gathering area }\end{array}$ & Banan gathering area & $\begin{array}{l}\text { Yongchuan } \\
\text { gathering area }\end{array}$ & $\begin{array}{l}\text { Jiulongpo Jiangjin } \\
\text { gathering area }\end{array}$ & $\begin{array}{l}\text { Dianjiang } \\
\text { gathering area }\end{array}$ & $\begin{array}{l}\text { Zhongxian } \\
\text { gathering area }\end{array}$ \\
\hline & $\begin{array}{l}\text { 1) Health and social } \\
\text { work } \\
\text { 2) Residential } \\
\text { services, repair and } \\
\text { other services }\end{array}$ & $\begin{array}{l}\text { 1) Health and social } \\
\text { work }\end{array}$ & $\begin{array}{l}\text { 1) Health and social } \\
\text { work }\end{array}$ & $\begin{array}{l}\text { 1) Health and social } \\
\text { work }\end{array}$ & $\begin{array}{l}\text { 1) Leasing and } \\
\text { business services }\end{array}$ & \multirow[t]{2}{*}{$\begin{array}{l}\text { 1) Health and } \\
\text { social work }\end{array}$} \\
\hline & $\begin{array}{l}\text { Fengdu gathering } \\
\text { area }\end{array}$ & Fuling gathering area & $\begin{array}{l}\text { Nanchuan gathering } \\
\text { area }\end{array}$ & $\begin{array}{l}\text { Qijiang gathering } \\
\text { area }\end{array}$ & $\begin{array}{l}\text { Yuzhong } \\
\text { gathering area }\end{array}$ & \\
\hline $\begin{array}{l}\text { Advantageous } \\
\text { enterprises }\end{array}$ & $\begin{array}{l}\text { 1) Health and social } \\
\text { work }\end{array}$ & $\begin{array}{l}\text { 1) Health and social } \\
\text { work } \\
\text { 2) Nursing homes and } \\
\text { services }\end{array}$ & $\begin{array}{l}\text { 1) Health and social } \\
\text { work }\end{array}$ & $\begin{array}{l}\text { 1) Health and social } \\
\text { work }\end{array}$ & $\begin{array}{l}\text { 1) Leasing and } \\
\text { business services }\end{array}$ & \\
\hline
\end{tabular}

repair and other services, leasing and business services, as well as nursing homes and elderly care service enterprises. Among them, health and social work enterprises have the greatest advantages, followed by residential services, repair and other services, which also shows that the elderly people attach importance to physical and life services.

\section{Conclusion}

Elderly care enterprise is an important industry around the cause of aging, so the reasonable distribution and cluster of elderly care enterprises is very important. At present, the distribution of elderly care enterprises in Chongqing is closely related to the degree of urbanization. Generally speaking, the higher the degree of urbanization, there are more elderly care industries. This is because there are more demands for elderly care in the regions with higher industrialization level 
or more developed economy. Therefore, there are more elderly care Enterprises around these areas.

From the perspective of the distribution of elderly care clusters, the current elderly care industry clusters in Chongqing are more prominent in Yubei-Jiangbei Aggregation Area and Yuzhong District. Their overall characteristics are the large number of elderly care enterprises, the large scale, high abundance and industrial age is reasonable. The industrial cluster in Yuzhong District is a social resource-driven industrial cluster, which not only has a rich aging market and old-age social enterprises, but also cultivates emerging old-age technology enterprises. Yubei-Jiangbei agglomeration area is a very new cluster, which belongs to science and technology. Resource-derived-driven industrial cluster, which uses the technological advantages of high-tech enterprises to develop into the elderly care market. The two elderly care industry clusters are both located in the main urban area, but there are still some shortcomings in the development of other districts and counties. The elderly care industry clusters in these districts and counties are usually industrial clusters formed on the basis of the original social resources. Not only are they small in scale, but also low in abundance, making it difficult to give full play to their industrial advantages. Therefore, for this part of the industrial clusters, some supporting industries should be developed in a targeted manner to broaden the richness of industries and improve industrial efficiency.

The innovation of this research lies in the following two points: First, the analysis of geographic information and data is carried out on the elderly care industry clusters, while the traditional research on the elderly care industry often lacks data; second, the evaluation indicators such as richness are proposed.

\section{Shortcomings}

Since the elderly care industry does not have a completely consistent concept, the classification of the elderly care industry clusters in this study is still relatively rough. In further research, we can consider further and better division of the elderly care industry, as well as the combination of fields, such as the combination of medical care and elderly care. Combination of real estate and elderly care, etc.

\section{Conflicts of Interest}

The authors declare no conflicts of interest regarding the publication of this paper.

\section{References}

Chongqing Statistical Information Network (2019). Chongqing Statistical Information Network. http://tjj.cq.gov.cn/zwgk_233/tjnj/wap.html

He, H. L., \& Li, X. D. (2020). Research on the Changes of China's Population Age Structures and Trend. Academic Exchange, 319, 135-142, 194.

Mu, G. Z. (2012). Dilemma and Countermeasures of Institutional Elderly Care Develop- 
ment in China. Journal of Huazhong Normal University (Humanities Social Science Edition), 51, 31-38.

Song, A., Zhao, Y. G., \& Wang, D. Q. (2018). Dilemma and Countermeasures of the Development of Elderly Care Enterprises in Chongqing-Based on the Perspective of Industrial Chain. Chongqing Administration (Public Forum), 19, 25-27.

$\mathrm{Xu}$, J. J. (2013). Construction Concept of Residential Elderly Care Complex-A Case Study of Jinhua Mountain and River Home for the Elderly. Doctoral Dissertation, Jinhua: Zhejiang Normal University.

Yan, X. H. (2008). Research on the Current Situation, Development Trend and Investment Opportunities of China's Elderly Care Enterprises. Xiamen: Xiamen University.

Yan, Y. P., Huang, M. Z., \& Zheng, Y. R. (2021). Study on the Changes of the Age Structure of China. Dongyue, 1, 148-163.

Zhai, P. C. (2013). Research on the Development Model of China's Elderly Care Real Estate Industry. Doctoral Dissertation, Chongqing: Chongqing University. 